\title{
Student's Compliance in Doing Physical Activities During COVID-19 Pandemic
}

\author{
Sutopo Patriajati ${ }^{1}$, Ayun Sriatmi ${ }^{2}$, Arnia Dian Kusuma Devi ${ }^{3}$ \\ \{sutopopatriajati@gmail.com ${ }^{1}$, ayunsriatmi@gmail.com², arniadkd@gmail.com³ \\ Universitas Diponegoro, Semarang, Indonesia ${ }^{1,2}$ \\ Diponegoro National Hospital, Semarang, Indonesia ${ }^{3}$
}

\begin{abstract}
The social \& physical distancing policies implemented by the government to prevent transmission of COVID-19 force school-age children to carry out various activities at home. Quarantine demands and online models of learning had an impact on children's tendency to static patterns through sitting, playing gadgets, eating, and sleeping. They also neglecting important physical activities that must be carried out to maintain stamina, growth, and health status, such as light exercise and sunbathe in the morning. The health status of students was key to their productivity in the future. The purpose of the study was to analyze the compliance of students from doing physical activity during COVID-19 pandemic and various influencing factors. This is a quantitative study with a cross-sectional approach to 167 students who became the sample of the study. Data collected online with google-form in early May 2020. Data be analyzed with the rank-spearman test. As many as $61.7 \%$ of students have good levels of compliance in doing physical activities. Variables of family support, communication interactions, perceived comfort and physical health status were shown to be positively correlated with adherence in doing physical activities ( $\mathrm{p}<0.05)$. Support and involvement of family members to jointly carry out physical activities on a regular basis could be done through intensive communication with parents to always invite and remind them. Health workers could monitor and evaluate it by involving the role of school teachers.
\end{abstract}

Keywords: Physical activities; Compliance; COVID-19 pandemic

\section{$1 \quad$ Introduction}

Until the beginning of July 2020, the cumulative number of COVID-19 cases in Indonesia reached 57,770 cases with a total of 2,934 deaths. Based on the data in the age group of 6-17 years old or in the school-age group, there was a positive COVID19 of $5.7 \%$ or around 3,293 people with a death of $0.6 \%$ or a total of 18 people.[1]

This description indicates that the spread of COVID-19 that occurred in groups of school children could increase if prevention efforts were not carried out properly. Data at the Ministry of Health shows an increase in the number of new cases that continue to increase every day. To anticipate its transmission, the government issued 
a Large-Scale Social Restriction (PSBB) policy as PP No. 21 of 2020 concerning Large-Scale Social Restrictions in the Context of Accelerating the Handling of COVID- 19 and Minister of Health Regulation No. 9 of 2020 concerning PSBB Guidelines. This policy is known as a form of social and physical distancing.

The COVID-19 pandemic had a significant impact on many sectors of people's lives, one of which was the education sector. Physical distancing policy is also implemented in the educational environment through efforts to eliminate activities in schools. It aims to break the chain of transmission of the virus and struck the curve of COVID-19 cases. The Minister of Education and Culture issued Circular No. 4 of 2020, one of which points to the educational activities in the Coronavirus Disease (COVID-19) emergency period carried out by online methods from home. This policy has implications for students' learning activities that take place online from home.

Based on data from the Ministry of Education and Culture, the total number of students from elementary to high school / vocational school and special school (SLB) is more than 44.6 million children, and more than 5 million are in Central Java.[2] All of these students must do distance learning with online methods that make children do more activities in the house and look at the gadget screen. Children cannot meet with friends and do physical outdoor activities. Surely this implicates the lack of outdoor activities, intensity exposed to sunlight, and social activities.

Prolonged physical activity and inactivity are associated with negative physical and mental health outcomes, such as loss of muscle and cardiorespiratory fitness, weight gain, psychosocial problems, and even poor academic performance. During the pandemic, the prevalence of physically inactive students increased from $21.3 \%$ to $65.6 \%$. Screen time considerably increases during the total pandemic (average +1730 minutes, or about 30 hours per week). Evidence shows that physical activity provides protection from viral infections, especially among vulnerable populations.[3]

Studies show that in the short term exercise can help the immune system find and deal with pathogens; and in the long run, regular exercise slows changes that occur in the immune system as we age, thereby reducing the risk of infection. [4] Lack of physical activity outdoor is also related to lack of body exposure to sunlight. Sun exposure helps the body make vitamin D naturally. Vitamin D can boost the immune system and help fight diseases, including heart disease, muscle sclerosis, flu, autoimmune diseases, and certain cancers.[5]

Sedentary lifestyles tend to continue to expand in technologically advanced societies. Increased use of social media, has reduced the amount of time a teenager has to exercise. Based on a study of students of SMAN 6 Surabaya, the majority of respondents had relatively low exercise habits $(52.6 \%)$ whereas, the intensity of using social media was high (57.1\%). The high intensity of the use of social media is related to low exercise habits.[6]

Therefore, governments, schools, health professionals, and parents need to be aware of severe situations and implement more effective physical activity interventions to minimize the negative impact of the COVID-19 pandemic on the health of children and adolescents.[3] 


\section{$2 \quad$ Material and Method}

This is a quantitative descriptive study with a cross-sectional approach. The study population was all school children in the province of Central Java as many as $5,141,607$ people (data for 2019). The sample size is 167 people with inclusion criteria, namely children who live in Central Java province, aged 10-19 years, and are still in school or student status (elementary, junior high, and high school). The number of samples is determined based on the answers to the online questionnaire sent back. Determination of a minimum age of 10 years with consideration of the ability to answer and understand all research questions. Exclusion criteria are respondents whose answers to the questionnaire are incomplete and / or unclear so they cannot be analyzed, and respondents who do not meet the inclusion criteria.

Collecting data with closed questionnaire instruments using Google-form due to the COVID-19 pandemic situation and social \& physical distancing policies that require staying at home so that face-to-face interviews are not possible. Data were collected in the early May 2020 period by distributing questionnaires to school children for 2 weeks. A total of 189 questionnaires were returned and after cleaning the data, 167 relevant data were obtained and followed up.

The independent variables of the study include characteristics (age, sex, education, and family status), knowledge, attitudes, perception of social distancing policy, perception of social impact, family support, perception of mental vulnerability, communication, comfort, and physical health status. The dependent variable is compliance in carrying out physical activities as measured by indicators of sports activities and sunbathing in the morning. Data were analyzed univariately with frequency distribution and bivariate analysis with crosstables and rank-spearman correlation tests because the data were not normally distributed.

\section{Result and Discussion}

Table 1. shows that the majority of school children who were respondents included the early adolescent group (ages 11-15 years). The average age is 14.82 years (SD 2.03) with the youngest age is 11 years and the oldest is 19 years. Most respondents were female and attended secondary school (SLTP and SLTA) with family status was not a JKN-KIS recipients. Most respondents have a good category for all variables even though the amount of proportion varies between variables. They also tend to be obedient to carry out physical activities routinely at $61.7 \%$. Walking activities around residential areas and neighborhoods, cycling, helping to wash vehicles, and cleaning the house is a form of physical activity that is often done by school children during quarantine due to the COVID-19 pandemic. In addition, they also try to sunbathe every morning for 10-15 minutes according to the advice of health workers and the information they receive from the mass media and social media they have. Table 1 also shows that although the proportion of respondents in the good category is higher for all variables in this study, some variables show very small differences in the proportion of differences, namely the variable perception of mental vulnerability, perception of social impact and family support. 
Table 1. Characteristic of students who were the sample of the study

\begin{tabular}{|c|c|c|c|c|}
\hline NO & VARIABLE & CATEGORIES & $\mathbf{N}$ & $\%$ \\
\hline \multirow[t]{4}{*}{1} & Age & a. Early teenager (11-15 & 104 & 62.3 \\
\hline & & y.o.) & 63 & 37.7 \\
\hline & & b. Older teenager (16-19 & & \\
\hline & & y.o.) & & \\
\hline \multirow[t]{2}{*}{2} & Sex & a. Male & 60 & 35.9 \\
\hline & & b. Female & 107 & 64.1 \\
\hline \multirow[t]{3}{*}{3} & Education & a. Elementary School & 36 & 21.6 \\
\hline & & b. Middle School & 53 & 31.7 \\
\hline & & c. High School & 78 & 46.7 \\
\hline \multirow[t]{2}{*}{4} & Family Status & a. JKN/KIS recipients & 23 & 13.8 \\
\hline & & $\begin{array}{l}\text { b. Not a JKN/KIS } \\
\text { recipients }\end{array}$ & 144 & 86.2 \\
\hline \multirow[t]{2}{*}{5} & Knowledge & a. Low & 63 & 37.7 \\
\hline & & b. Good & 104 & 62.3 \\
\hline \multirow[t]{2}{*}{6} & Attitude & a. Low & 55 & 32.9 \\
\hline & & b. Good & 112 & 67.1 \\
\hline \multirow[t]{2}{*}{7} & Perception to the issue of & a. Low & 74 & 44.3 \\
\hline & Social \& Physical Distancing & b. Good & 93 & 55.7 \\
\hline \multirow[t]{2}{*}{8} & Perception to the social & a. Great & 79 & 47.3 \\
\hline & implication & b. Low & 88 & 52.7 \\
\hline \multirow[t]{2}{*}{9} & Family support & a. Low & 78 & 46.7 \\
\hline & & b. Good & 89 & 53.3 \\
\hline \multirow[t]{2}{*}{10} & Perception to the mental & a. Great & 83 & 49.7 \\
\hline & vulnerability & b. Low & 84 & 50.3 \\
\hline \multirow[t]{2}{*}{11} & Communication & a. Low & 72 & 43.1 \\
\hline & & b. Good & 95 & 56.9 \\
\hline \multirow[t]{2}{*}{12} & Comfort & a. Low & 74 & 44.3 \\
\hline & & b. Good & 93 & 55.7 \\
\hline \multirow[t]{2}{*}{13} & Physically health-status & a. Low & 43 & 25.7 \\
\hline & & b. Good & 124 & 74.3 \\
\hline \multirow[t]{2}{*}{14} & Compliance with physical & a. Low & 64 & 38.3 \\
\hline & activity & b. Good & 103 & 61.7 \\
\hline
\end{tabular}

The low difference between the proportion of children with a perception of great mental vulnerability with a low indicates that the COVID pandemic raises two different dimensions of understanding. There are some children who feel depressed, confused, and stressed, but on the other hand, there are also children who feel happy because they can play freely and are not bound to go to school. The same relative condition also occurs in the perception variable of social impacts felt during the COVID-19 pandemic.

Regular physical activity (such as walking, running, and exercising) increases the cardiovascular functional ability and is beneficial in reducing the risk of chronic diseases such as obesity, heart disease, stroke, type 2 diabetes mellitus, over nutrition and depression. Therefore, physical activity must be carried out routinely and structured. Other benefits of physical activity include increasing endurance, strengthening muscles and bones, maintaining ideal body weight, and increasing fitness.[7] 
On the other hand, physical activity can also reduce mental depression (stress), increase self-confidence and a sense of responsibility, and help maintain optimal health.

Several studies prove that the current COVID-19 pandemic situation is causing anxiety in families and communities, including children as family members. [8] Anxiety is mainly related to fear and risk of contracting the disease, and uncertainty when this situation ends. Prolonged anxiety can cause mental depression such as sleep disturbance, fear of interacting with others, abuse of illegal drugs, and a decrease in the immune system which makes children more vulnerable to certain diseases. Komalasari's research in Padang also proved that anxiety is related to depression experienced by students.[9]

Table 2. Cross-Tabulation Relationship of the Independent to the Research Variables

\begin{tabular}{|c|c|c|c|c|c|c|}
\hline \multirow{3}{*}{ No } & Independent Variable & \multicolumn{4}{|c|}{ Compliance In Physical Activity } & \multirow[t]{2}{*}{$\mathbf{P}$} \\
\hline & & \multicolumn{2}{|l|}{ Low } & \multicolumn{2}{|c|}{ Good } & \\
\hline & & $\mathrm{N}$ & $\%$ & $\mathrm{~N}$ & $\%$ & \\
\hline \multirow[t]{3}{*}{1} & Age & & & & & \\
\hline & a. Early teenagers (11-15 y.o.) & 37 & 35.6 & 67 & 64.4 & 0.471 \\
\hline & b. Older teenager (16-19 y.o.) & 27 & 42.9 & 36 & 57.1 & \\
\hline \multirow[t]{3}{*}{2} & Sex & & & & & \\
\hline & a. Male & 24 & 40.0 & 36 & 60.0 & 0.712 \\
\hline & b. Female & 40 & 37.4 & 67 & 62.6 & \\
\hline \multirow[t]{4}{*}{3} & Education & & & & & \\
\hline & a. Elementary school & 10 & 27.8 & 26 & 72.2 & \\
\hline & b. Middle school & 19 & 35.8 & 34 & 64.2 & \\
\hline & c. High school & 35 & 44.9 & 43 & 55.1 & \\
\hline \multirow[t]{3}{*}{4} & Family status & & & & & \\
\hline & a. JKN/KIS recipient & 8 & 34.8 & 15 & 65.2 & 0.964 \\
\hline & b. Not a JKN/KIS recipient & 56 & 38.9 & 88 & 61.1 & \\
\hline \multirow[t]{3}{*}{5} & Knowledge & & & & & \\
\hline & a. Low & 24 & 38.1 & 39 & 61.9 & 0.517 \\
\hline & b. Good & 40 & 38.5 & 64 & 61.5 & \\
\hline \multirow[t]{3}{*}{6} & Attitude & & & & & \\
\hline & a. Low & 21 & 38.2 & 34 & 61.8 & 0.068 \\
\hline & b. Good & 43 & 38.4 & 69 & 61.6 & \\
\hline \multirow[t]{3}{*}{7} & $\begin{array}{l}\text { Perception to the issue of Social \& } \\
\text { Physical Distancing }\end{array}$ & & & & & \\
\hline & a. Low & 27 & 36.9 & 47 & 63.5 & 0.778 \\
\hline & b. Good & 37 & 39.8 & 56 & 60.2 & \\
\hline \multirow[t]{3}{*}{8} & Perception to the social implication & & & & & \\
\hline & a. Great & 33 & 41.8 & 46 & 58.2 & 0.376 \\
\hline & b. Low & 31 & 35.2 & 57 & 64.8 & \\
\hline \multirow[t]{3}{*}{9} & Family support & & & & & \\
\hline & a. Low & 36 & 46.2 & 42 & 53.8 & $0.001^{*}$ \\
\hline & b. Good & 28 & 31.5 & 61 & 68.5 & \\
\hline \multirow[t]{3}{*}{10} & Perception to the & & & & & \\
\hline & vulnerability & 33 & 39.9 & 50 & 60.2 & 0.155 \\
\hline & $\begin{array}{l}\text { a. Great } \\
\text { b. Low }\end{array}$ & 31 & 36.9 & 53 & 63.1 & \\
\hline
\end{tabular}


11 Communication

\begin{tabular}{|c|c|c|c|c|c|c|}
\hline & a. Low & 37 & 51.4 & 35 & 48.6 & $0.005^{*}$ \\
\hline & b. Good & 27 & 28.4 & 68 & 71.6 & \\
\hline \multirow{3}{*}{12} & Comfort & & & & & \\
\hline & a. Low & 34 & 45.9 & 40 & 54.1 & $0.011^{*}$ \\
\hline & b. Good & 30 & 32.3 & 63 & 67.7 & \\
\hline \multirow[t]{3}{*}{13} & Physically health status & & & & & \\
\hline & a. Low & 21 & 48.8 & 22 & 51.2 & $0.038 *$ \\
\hline & b. Good & 43 & 34.7 & 81 & 65.3 & \\
\hline
\end{tabular}

Significant in $\mathrm{p}<0.05$ with Rank-Spearman test

The correlation test indicates that partially, the variables of family support, ongoing communication, amenities, and physical health status show a significant correlation with school children's adherence to physical activities because the p-value obtained from the statistical test is less than $0.05(\mathrm{p}<0.05)$. The direction of the relationship is also positive. While the variable characteristics, knowledge, attitudes, policy perceptions, perceptions of social impact, and perceptions of mental vulnerability are not statistically related. These results also indicate that family support and ongoing communication interactions have a very close relationship (see Table 2).

Family support has been shown to be related to adherence to children in carrying out various exercises and other physical activities. Conceptually, family support can be divided into 4 dimensions, namely instrumental support, informational support, appreciation support, and emotional support.[10],[11] Social support in the form of facilitation of needs and facilities in various activities carried out by family members, informational support in the form of advice and clear explanations. Appreciation support can take the form of assessments of achievements and positive performance achievements generated as feedback, while emotional support can be in the form of feelings of sympathy, empathy, and care for the problems faced by family members.

Social support provided by the family plays an important role in the physical, mental, and emotional development of children because of interpersonal relationships and interactions between family members that create very strong emotional bonds. Relationships between family members and emotional life influence each other in the family.[12] The role of the family, especially parents, gives children the first experience and social adaptation in each of their behavioral practices, including the practice of maintaining physical health and fitness through sports and various other physical activities. The form of social support provided refers to the four dimensions, such as providing information, advice, direction, exchanging opinions when children are facing problems, the provision of sports equipment and facilities needed, involved in jointly doing sports, as well as providing time to listen to all his complaints. Other support can also be in the form of incentives and disincentives such as gifts for doing positive things and fines or penalties for doing negative things.

Family as the smallest element of society occupies the main position which is fundamental in influencing the life of a child, especially in critical times. In essence, the family is a container for the formation of the character, attitudes, and behavior, including in the behavior of maintaining physical and mental health status. These results are in line with research in Malang which proves that there is a positive relationship between family social support and the career maturity of junior high school students.[11] Larasati et al's research also indicate that family support contrib- 
utes to the development of children's psychology. Family support not only provides support for children but also other groups, such as the elderly group, as Atmaja \& Rahmatika's research proves that family social support influences the motivation of the elderly group to maintain their health through physical activity.[13] Morrissey et al's study in the USA proves that family support and friend support are predictors of the increased activity and intensity of adolescents doing exercise.[14] Studies in China also show that parental support for sports and physical activity is very important in promoting and facilitating the participation of school children in moderate-tovigorous physical activity (MVPA).[15]

The COVID-19 pandemic situation, directly and indirectly, contributes to the health status of children, including school-age children. Although the risk of exposure to COVID-19 is lower in children, confusion over the situation and unclear family destinies have a major impact on children. The negative effects of school closure and the necessity of online learning models have the potential to make children anxious, stressed, depressed, and feel isolated from their environment. Changes in learning patterns from originally face-to-face directly to online-based trigger emotional vulnerability and discomfort. Hence, the role and support of parents, as well as other family members during the COVID-19 pandemic quarantine becomes the most important thing for children.[16]

For further information, communication interactions that are established between school children and family members, with friends, class teachers, and everyone in their environment contribute to the participation and compliance of various healthy physical activities. Communication interaction refers to the mechanism of delivering messages that can influence decision making. Communication also includes information dissemination activities that can increase awareness, change attitudes and behavior, and motivate healthy behavior.[17] Poor communication results in misperceptions, misinterpretations, and conflicts that result in poor compliance, including compliance with various physical activities by school children in a COVID-19 pandemic situation. Children will tend to remain in the room while sleeping, eating, watching TV, or playing gadgets which incidentally is a very small mechanism of motion.

School-age children need a lot of information in shaping the character of their soul. They tend to be easily influenced by something that is considered new and good, although not healthy. Therefore, groups of teenagers and school children are often easy targets for advertisements that tend to neglect health. Although lots of other communication strategies, the best communication strategy from parents and families towards children is exemplary. Being a role model, parents should give real examples of proper health behavior, one of which is carrying out physical activities to maintain fitness and endurance.[12]

Communications related to the patterns of relationships with others that include the process of interaction and its meaning. A person's character will be formed from ongoing interpersonal communication interactions. The purpose of interpersonal communication carried out in the family is to strengthen social relations between individuals in the family (family members), as well as a function of socialization in instilling values and norms that must be obeyed. The communication model can be in the form of verbal and non-verbal. Verbal communication forms are seen based on the use of language, intonation, tone, and volume during speech or dialect and dialect, 
while non-verbal communication can be done through facial expressions, eye gaze, gestures, and appearance. Non-verbal communication models further strengthen verbal communication.[18] Prabandari \& Rahmiaji explained further that the habit of using mobile phones as a technology-based communication medium that is not well controlled by parents can reduce opportunities for direct communication between children and parents at home. The existence of this technology is a factor reducing the portion of direct communication that exists and can reduce the quality of communication (response, openness) of children to parents. The effectiveness of family communication is determined by the attitude of parents towards the use of smartphones.[19]

School-age children is a period where they seek and develop their personal identity. The process of finding identity is largely determined by the information it receives from various sources and media, especially from family at home, friends, and teachers at school and from the community in the surrounding environment. Immature psychological and mental development in adolescents has an impact on the inability to filter out all information received. Advances in web-based technology and the internet in social media provide unlimited space in the interaction of information and communication that can have negative implications for behavior. The rapid development of information technology makes mass media a necessity and an important part of modern life. The mass media is able to provide information and knowledge that shape perception. The research of Sriyanto et al proved that the mass media influences assertive behavior and juvenile delinquency tendencies. This result is also in line with McQuail's opinion that the influence of the mass media is very strong in shaping behavior.[12]

Other variables that also contribute to adherence to physical activity in school children are perceived dimensions of comfort and physical health status. The higher the comfort felt as the effect of various physical activities carried out will increase compliance to more routinely do it. If the physical health status of the children is in top condition, they tend to increase their willingness and motivation to exercise and sunbathe in the morning, as suggested by health workers. These results are in line with the research of Alamsyah et al. Which proves that there is a positive correlation between physical fitness and physical activities undertaken by students of SMK 11 Semarang City.[20] Romansyah et al's research also shows a relationship between perceived body image disturbance and sports activities undertaken.[21]

\section{Conclusion and Suggestion}

This study indicates that family support, ongoing communication, comfort, and physical health status show a significant correlation with schoolchildren's compliance with physical activities. Family support has been shown to be related to child compliance - namely instrumental support, informational support, appreciation support and emotional support. The best communication strategy from parents for children is exemplary in doing exercises and many healthy activity. Support and involvement of family members to jointly carry out physical activities on a regular basis could be done through intensive communication with parents to always invite and 
remind them. Health workers could monitor and evaluate it by involving the role of school teachers.

\section{References}

[1] Gugus Tugas Percepatan Penanganan Covid-19. Data COVID-19 Berdasarkan Kelompok Umur [Internet]. 2020. Available from: www.covid19.go.id

[2] Kementerian Pendidikan dan Kebudayaan. Data Peserta Didik [Internet]. 2019 [cited 2020 Jul 1]. Available from: www.dapo.dikdasmen.kemdikbud.go.id/pd

[3] Mi X, Zhang ZZ, Kuwahara K. Impact of COVID-19 pandemic on children and adolescents' lifestyle behavior larger than expected. Elsevier Public Heal Emerg Collect. 2020;PMC7190470.

[4] Simpson RJ, Campbell JP, Gleeson M, Krüger K, Nieman DC, Pyne DB, et al. Can exercise affect immune function to increase susceptibility to infection? Exerc Immunol Rev. 2020;26(January):8-22.

[5] Gallagher G. Is Sunbathing Good for You? Benefits, Side Effects, and Precautions. [Internet]. 2019 [cited 2020 Jul 1]. Available from: https://www.healthline.com/health/sunbathing

[6] Setiawati FS, Mahmudiono T, Ramadhani N, Hidayati KF. Intensitas Penggunaan Media Sosial , Kebiasaan Olahraga , dan Obesitas Pada Remaja Di SMA Negeri 6 Surabaya Tahun 2019 Intensity of Social Media Usage, Exercise Habits , and Obesity among Adolescent in Senior High School 6 Surabaya 2019. Amerta Nutr. 2019;142-8.

[7] Nieman DC, Wentz LM. The compelling link between physical activity and the body's defense system. J Sport Heal Sci. 2019;8(3):201-17.

[8] Nurkholis. Dampak Pandemi Novel-Corona Virus Disease (Covid-19) terhadap Psikologi dan Pendidikan serta Kebijakan Pemerintah. J PGSD. 2020;6(1):3949.

[9] Komalasari W. Hubungan Kecemasan Orang Tua dengan Depresi pada Anak Sekolah Dasar di SDN 03 Simpang Haru Padang. Menara Ilmu. 2019;XIII(2):136-40.

[10] Larasati T, Mubin MF, Targunawan T. Dukungan Keluarga terhadap Perkembangan Psikologi: Konsep Diri Anak Usia Sekolah Dasar Di Wilayah Banjir ROB Kelurahan Bandarharjo Semarang Utara. J Imu Keperawatan dan Kebidanan. 2015;3:1-9.

[11] Rahma U, Rahayu E. Peran Dukungan Sosial Keluarga dalam Membentuk Kematangan Karier Siswa SMP. J Ilmu Kel dan Konsum. 2018;11(3):194-205.

[12] Sriyanto S, Abdulkarim A, Zainul A, Maryani E. Perilaku Asertif dan Kecenderungan Kenakalan Remaja Berdasarkan Pola Asuh dan Peran Media Massa. J Psikol. 2014;41(1):74.

[13] Atmaja RAJ, Rahmatika R. Peran Dukungan Sosial Keluarga terhadap Motivasi Menjaga Kesehatan melalui Aktifitas Fisik pada Lansia. J Psikogenes. 2017;5(2):180-7. 
[14] Morrissey JL, Janz KF, Letuchy EM, Francis SL, Levy SM. The effect of family and friend support on physical activity through adolescence: A longitudinal study. Int J Behav Nutr Phys Act. 2015;12(1):1-9.

[15] Liu Y, Zhang Y, Chen S, Zhang J, Guo Z, Chen P. Associations between parental support for physical activity and moderate-to-vigorous physical activity among Chinese school children: A cross-sectional study. J Sport Heal Sci. 2017;6(4):410-5.

[16] Pradana AA, Casman C, Nur'aini N. Pengaruh Kebijakan Social Distancing pada Wabah COVID-19 terhadap Kelompok Rentan di Indonesia. J Kebijak Kesehat Indones. 2020;9(2):61-7.

[17] Rahmadiana M. Komunikasi Kesehatan: Sebuah Tinjauan*. J Psikogenes. 2012;1(1):88-94.

[18] Sari A, Hubeis A, Mangkuprawira S, Saleh A. Pengaruh Pola Komunikasi Keluarga Dalam Fungsi Sosialisasi Keluarga Terhadap Perkembangan Anak. J Komun Pembang. 2010;8(2):36-45.

[19] Prabandari AI, Rahmiaji LR. Komunikasi Keluarga dan Penggunaan Smartphone oleh Anak. Interak Online. 2019;7(3):224-37.

[20] Alamsyah DAN, Hestiningsih R, Saraswati LD. Faktor-Faktor Yang Berhubungan Dengan Kebugaran Jasmani Pada Remaja Siswa Kelas Xi Smk Negeri 11 Semarang. J Kesehat Masy. 2017;5(3):77-86.

[21] Romansyah M, Natalia D. Gangguan Body Image dihubungkan dengan Aktivitas Olahraga pada Mahasiswa Obesitas. J STIKES. 2012;5(1):1-10. 